MIr. G. Hone, valuer, said the outside rent that could be obtained for the premises was $£ 15$ a year.

On behalf of the Corporation, some other evidence was given, and it was stated that the freehold of a registered slaughter-house in Cheltenham, with lairs, yard, stables, etc., all in a superior structural condition to the premises in question, had been sold within the previous year for the sum of $₫ 275$.

AWARD.-A few days later the arbitrator issued his award for f198. Each party to pay their own costs. He appended the following memorandum :

I find the net cost to be at the very most $\$ 12$ a year. On account of the age, bad state of repair, and, in part, ruinous state of the premises, I capitalize this at fifteen years' purchase.

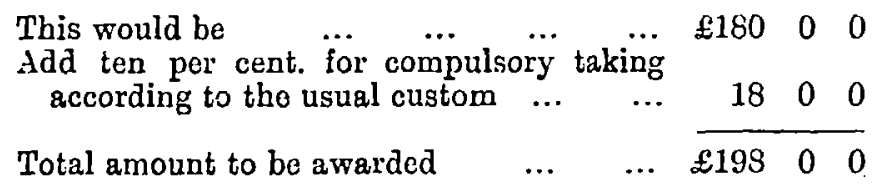

\title{
THE ABATTOIR OF BIARRITZ.
}

Br AIICE I. CUMMING, M.B., C.M., D.P.H. Casm.

IN the present crusade against tuberculosis, the municipal control of the slaughter of animals for food and subsequent inspection is a matter of vital importance. Throughout Great Britain this control is exercised only in comparatively few of the laiger towns. It may be of interest to describe the plan and general management of the public abattoir of Biarritz, as the arrangements there seem capable of being adapted to the needs of small towns in this country.

Biarritz is a town of 10,000 inhabitants, but receives during the year about 20,000 visitors, as it is well lnown and appreciated as a health-resort in early spring by the English, and as a summer watering-place by the French and Spaniards.

Until 1898, although the slaughtering of animals for food was carried on under the control of the town officials, only sheds in somewhat close proximity to dwelling-houses were available for the purpose. In that year the present abattoir was opened, situated about $1 \frac{1}{2}$ miles from the town, in an isolated poșition among the sandhills, overlooling'the sea.

The following is a plan of the abattoir, which consists of a large space (295 feet by 154 feet) enclosed by high walls, within which are sheds for the reception of animals before slaughter, a large 
central building of one story (I), divided into apartments, where the animals are lilled, and other buildings used as scalding (rI), salting (Ix), and tripe houses (riI).

Outside the entrance-gate there is a shed (xir) where the animals are sheltered while awaiting the daily visit of the veterinary surgeon, who examines them before admission. If passed as

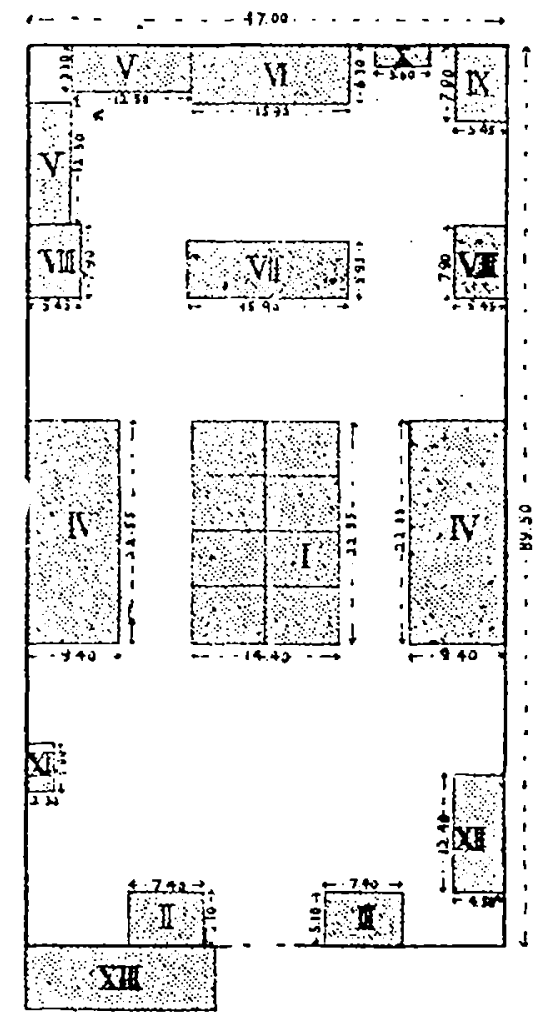

Explanations.

I. lilling rooms.
II. Porter's lodge.
III. Office.
Ir. Cattle lairs.
v. Pig lens.
VI. Scalding house.

XIII. Shed.
VII. Tallow house.

VIII. Tripe house.

IX. Salting louse.

$\mathrm{X}$. Lavatories.

XI. Manure pit.

XII. Stables.

healthy and sound, the animals are taken into the abattoir and weighed. The town dues and fees for the use of the abattoir are paid at the office (III), and each animal is given a number, according to which the butchers take their turn of the killing-rooms in rotation. Separate lairs are provided for oxen, sheep, pigs, and wild bullocks, above being stores of bedding and food-stuffs. All 
animals must remain at least twenty-four hours in the abattoir before slaughter, with the exception of calves, which may be lilled immediately on being brought in. During this interval the animals must be supplied with food and water, the bedding being provided by the authorities, who retain and dispose of the manure.

The large central building (I) is divided into eight compartments for the slaughter of oxen, cows, and sheop (pigs are killed in a separate building); and each compartment is lighted from the roof, has a water and gas supply, and walls and flooring composed of cement, impermeable and easily cleansed. After slaughter, during which the doors are closed, the carcasses are dressed and hung upon suitable pulleys; the liver, heart, and lungs are also exposed for inspection, and the intestines and offal are taken to the tripe-house. The scalding-house (vr), where the pigs are killed, has also cement walls and flooring, with gutters for waste-water, and hot-water pipes lead to cemented tubs for scalding and scraping the skins. Fresh hot water must be used for each animal, and the fuel required is paid for by the pork-butchers.

The inspecting officer, a veterinary surgeon, in the pay of the municipality, visits the abattoir once daily in winter, and twice daily in summer, and all animals or parts thereof considered by him to be unsound and unfit for human food are confiscated, soaked in petroleum, burnt, and buried in the presence of the employés of the abattoir. All sound meat is stamped at the time of the inspection, and a special indelible ink is employed, with a combination of letters changed daily to prevent fraudulent imitation.

Compensation to the value of the animal seized is given by the State to those butchers who, before slaughter, declare the fact that their animal is unhealthy.

Scrupulous cleanliness is enforced by the management. Each butcher has to scrape and wash the walls and floor of the compartment he has used and leave it ready for the next-comer. All solid refuse is taken to the manure pits, which are emptied daily in summer, and every second day in minter, and all waste water is led into a large tank outside the walls, which is emptied at each high tide.

Receptacles are provided for butchers who desire to collect blood or tallow (vir) for commercial purposes, but the blood must be removed daily, and the tallow every five days in the summer. 'In cold weather a longer time is allowed.

T'he butchers have the use of the tripe-house (vir) for cleaning and cooking of tripe. No internal organs may be removed from it unless properly cleansed. Each butcher pays for his own fuel, 
provides the necessary utensils for his business, and must keep these clean, and thoroughly wash out the place after use.

According to municipal regulations, no animals-viz., oxen, cows, calves, sheep, lambs, pigs-intended for food may be killed in Biarritz elsewhere than in the public abattoir, except in the case of farmers who lill pigs for their own use, and then only if an enclosed space, apart from the public road and conforming to sanitary regulations, is used.

Animals must be brought directly to the abattoir, and may not be taken into the town and retained there in any stable or cowshed.

The veterinary surgeon has the same right to confiscate unsound dead meat brought into the town from $\dot{\mathbf{a}}$ distance, and must examine all such meat brought in, only that bearing the stamp of some other recognised abattoir being allowed to pass unchallenged, if within a certain number of days from the date on the stamp.

In the public market the commissaires de police keep watch to see that no unstamped meat is sold. The points to notice are:

1. The favourable hygienic position of the abattoir preventing probability of nuisance.

2. The inspection of animals both before and after slaughter.

3. The giving of compensation in certain cases.

4. The absolute cleanliness and order which everywhere prevail.

5. The avoidance of unnecessary cruelty by killing the animals in separate compartments, with closed doors.

There are relatively fow cases of tuberculosis detected among the animals. Perhaps the use of oxen and cows as beasts of burden, and the climate, which permits them to be out of doors almost the whole year, may be partly the cause of this freedom.

PuS IN MiLk.-The St. Pancras Vestry recently submitted certain samples of milk for bacteriological and microscopical examination, with the result that in five of the samples pus was reported to be present. The matter was referred to the Health Committee of the vestry to consider how far it was possible to take legal action for the sale of such milk under the Publie Health (London) Act, 1891, as unsound food; and the committee submitted the question for the opinion of counsel. Acting upon this advice, the committee recommended that summonses should be issued on behalf of the vestry against the cow-keepers in each of the cases where pus was found to be present. There was a lengthy discussion at the vestry upon this recommendation, and it was rejected. An amendment to the effect that cow-keepers and persons engaged in the distribution of milk in St. Pancras should be informed that all samples of milk taken by the inspectors under the Food and Drugs Acts would in future be subjected to bacteriological examination, and where the analysis justified it prosecutions would be issued, was carried.-British Food Journal. 